\title{
Edibility assessment of the swimming crab Charybdis natator (Brachyura: Portunidae) from the Gulf of Suez, Red Sea, Egypt
}

\author{
Wafaa S. Sallam ${ }^{1}$ and Amaal A-F.A. Gab-Alla ${ }^{2}$. \\ 1 - Department of Marine Sci., Fac. of Sci., Suez Canal Univ., Ismailia, Egypt. \\ 2- Food Technology Lab., Fac. of Agriculture, Suez Canal Univ., Ismailia, Egypt.
}

\begin{abstract}
The portunid crab Charybdis natator exists in the commercial catches of the 1 Gulf of Suez trawlers in a considerable quantity. Although edible worldwide, this crab is hardly known among local consumers. This study aimed to assess the suitability of this crab as food. Examination of the muscle tissues was carried out in terms of biochemical composition (protein, lipids and carbohydrates) and the accumulation of the heavy metals $(\mathrm{Cd}, \mathrm{Cu}, \mathrm{Fe}, \mathrm{Pb}$ and $\mathrm{Zn})$. Organoleptic differences among the cooked meat of this species and that of the popular species Portunus pelagicus were tested. Protein constituted over $80 \%$ of the muscles dry weight of male and female crab, followed by lipids (7.25-7.79\%) and carbohydrates (5.39-6.26\%) respectively. $\mathrm{Zn}$ was the highest accumulated metal $(46.6,45.4 \mathrm{ppm})$ followed by $\mathrm{Cu}(24.4,36.6 \mathrm{ppm}), \mathrm{Fe}(21.8$, $36.2 \mathrm{ppm})$ and $\mathrm{Pb}(3.9,4.6 \mathrm{ppm})$, while $\mathrm{Cd}$ was the lowest (0.9ppm) in males and females respectively. Intra-specific and size-based variations in metal uptake were recorded. Test of organoleptic qualities ranked P. pelagicus as higher in all attributes. However, no significant difference was observed in the total acceptability of the two species $(\mathrm{P} \geq 0.05)$. The study highlighted the suitability of $C$. natator as edible, nutritive and safe seafood.
\end{abstract}

Key words: swimming crab, Charybdis natator, Red Sea, assessment, edibility.

\section{INTRODUCTION}

The portunid crab Charybdis natator (Herbst), 1789 is found in the Indian and western Pacific oceans (Stephenson et al., 1958), where it contributes to crab fisheries in India (Menon, 1952) and Australia, although it is less common in comparison to other more abundant and commercially important species such as Portunus pelagicus and Scylla serrata.

In the Suez Canal area and the Egyptian coast of the Mediterranean, only Portunus pelagicus is exploited commercially. The biology of this species has been extensively studied in both the Mediterranean (Alkholy and Elhawary, 1970; Abdel Razek, 1988; Bawab and Elsherif, 1988, 1989) and Red Sea waters (Zaghloul, 2003) as well as other parts of the world (Batoy et al., 1988, 1989; Kangas, 2000; Wang et al., 2001). In contrast, very little is known of the biology of Charybdis natator in any area of its distribution (Sumpton, 1990 a, b). 
Information on records of occurrence was given by Barnard (1950) and taxonomic descriptions by Stephenson et al. (1958).

Considerable studies have also been carried out on the biochemical composition and heavy metals accumulation in P. pelagicus of the Egyptian waters (Ghazaly, 1988; Zaghloul, 2003; Sallam et al., 2006). Nevertheless, none were carried out on Charybdis natator of the Red Sea and only few on other species, such as C. hellerii in Pakistan (Siddiquie et al., 1978) and C. smithii in India (Balasubramanian \& Suseelan, 2001). On the other hand, no information is available on the organoleptic qualities of the cooked meat of both species inhabiting the Egyptian coasts of the Mediterranean and the Red Seas.

Charybdis natator appears in the catches of commercial fish species of the Gulf of Suez trawlers operating close to Gemsha Islands. Although existing in reasonable quantities, it is considered as a by-product and introduced occasionally to the markets in Suez town. Since landing data of this species are incorporated with those of $P$. pelagicus, no separate estimates regarding the catch per unit effort with the time of day, with the season or the area are available. Despite being known as an edible species worldwide, this crab has a fairly low popularity among consumers in Suez. The reluctance of local consumers to purchase this species is attributed to its extremely hard carapace that has led to its common name (the rock crab) and to the rocky substrate from which this species is being fished. The fact that it is a neglected species has stimulated the study of evaluating its suitability for human consumption. Assessment was carried out in terms of 1- biochemical composition 2- accumulation of a number of heavy metals in the muscle tissues and 3- organoleptic differences among its cooked meat and that of the popular species Portunus pelagicus.

\section{MATERIALS AND METHODS}

Fresh samples of $C$. natator were collected from the catches of the trawling vessels at the landing site of El-Ataka Port on the Gulf of Suez on December 2007. Specimens were measured for carapace width (CW) by means of vernier calipers. A total of 27 crabs, 15 female and 12 male were chosen for analysis (three replicates of each sex from each size range). They were dissected and gonad condition determined. Only individuals with immature gonads were used. The meat from the abdomen was extracted, a heavy pestle was used to crack the chelipeds and the meat was removed by means of a spatula.

The extracted flesh was divided into two equal amounts. The first was oven dried at $60^{\circ} \mathrm{C}$ until constant weight was obtained then desiccated for two days. $25 \mathrm{mg}$ of the dried tissues was added to $1 \mathrm{ml}$ of $10 \%$ trichloroacetic acid, centrifuged for 20 minutes at 3000rpm and the precipitate was analysed for protein according to Lowry et al. (1951). The supernatant was used for carbohydrates analysis according to Dubois et al. (1956). The total lipid was estimated by sulphophosphovabillin method of Branes and Blackstock (1973). 
The second quantity of flesh was used for analysis of heavy metals. Lyophilised crushed and homogenized tissues (ca $0.4 \mathrm{~g}$ ) were digested with $1 \mathrm{ml}$ Suprapur (Merck) nitric acid at $120^{\circ} \mathrm{C}$ for 2 hours, according to APHA (1995). The resultant solutions were diluted to a known volume with double-distilled deionized water. The trace metals $\mathrm{Cu}, \mathrm{Cd}, \mathrm{Pd}, \mathrm{Fe}$ and $\mathrm{Zn}$ were analysed by Perkin Elmer atomic absorption Analyst 100 equipped with hydride system and graphite furnace. The analytical procedure was checked using a reference material (MA- MEDPOL-1/TM) (IAEA, Monaco). Values were expressed as $\mathrm{mg} / \mathrm{kg}$.

Another random sample of intact individuals of both $C$. natator and Portunus pelagicus was obtained for testing the organoleptic qualities of meat. Crabs were cooked separately in boiling water and the meat from the abdomen and chelipeds was extracted manually using a spatula. Cooking has rendered the carapace of C. natator rather fragile so that no difficulty was encountered during meat extraction. An evaluation of organoleptic qualities of crab's meat was performed by aid of ten panelists according to Klein and Bardy (1984). The selected organoleptic terms were: aroma (freshness), color, texture, taste and acceptability. The fresher, whiter, firmer, juicier and more acceptable meat was ranked higher in score. The score was divided into10 points as follows: 9-8 very good; 7-6 good; 5-4 fair; 3-1 poor.

\section{RESULTS}

The mean percentages of the different biochemical components of the muscle tissue of C. natator are presented in Table 1. Protein was apparently the major constituent of muscles amounting for about $80 \%$ of dry weight of both sexes followed by lipids (7.25-7.79\%) and carbohydrates (5.39-6.26\%) for male and female respectively. Figures 1 and 2 display the mean percentages of the different biochemical components in relation to the crab's body size (mm CW). The largest males, with carapace width between $130-140 \mathrm{~mm}$, had the highest protein percentage $(88.5 \%)$, the lowest lipids $(5.4 \%)$ and carbohydrates $(2.3 \%)$ respectively (Fig.1).

Table 1: Mean percentages of the biochemical components determined in the muscle tissues of Charybdis natator

\begin{tabular}{|c|cc|lc|lr|}
\hline \multirow{2}{*}{ Sex } & \multicolumn{2}{|c|}{ Protein } & \multicolumn{2}{c|}{ Lipids } & \multicolumn{2}{|c|}{ Carbohydrates } \\
\cline { 2 - 7 } & Range & Mean \pm SD & Range & Mean \pm SD & Range & Mean \pm SD \\
\hline Male & $78.37-88.46$ & $82.35 \pm 4.4$ & $5.41-7.83$ & $7.25 \pm 1.3$ & $2.89-8.95$ & $5.39 \pm 2.6$ \\
Female & $68.80-89.80$ & $81.29 \pm 6.9$ & $5.37-12.53$ & $7.79 \pm 2.3$ & $2.3-11.09$ & $6.26 \pm 3.3$ \\
\hline
\end{tabular}

Legend: $\mathrm{SD}=$ Standard deviation . 


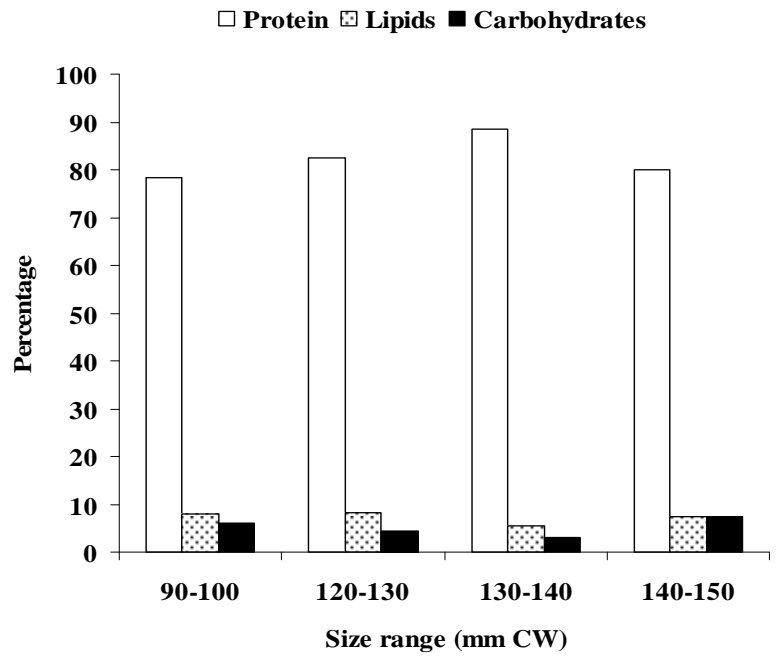

Fig. (1). Mean percentages of the different biochemical components of the muscle tissues of male $C$. natator in relation to body size.

The same trend was observed for the largest. Those falling within the size range $120-130 \mathrm{~mm}$ also had the highest values for protein $(85.5 \%)$, the lowest values for lipids (5.4\%) and carbohydrates (4.9\%) respectively (Fig.2).

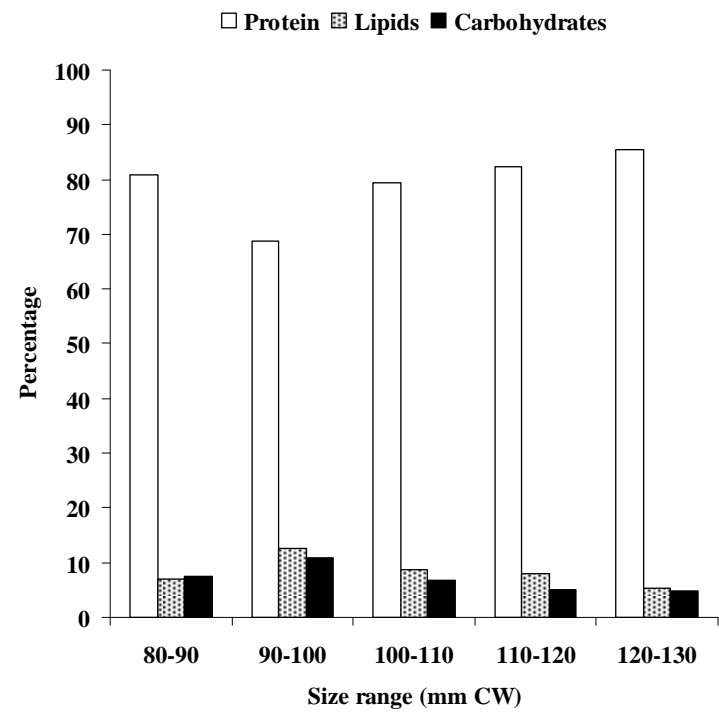

Fig. (2). Mean percentages of the different biochemical components of the muscle tissues of female C. natator in relation to body size. 
Mean concentrations ( $\mathrm{mg} / \mathrm{kg}$ ) of the heavy metals $\mathrm{Cd}, \mathrm{Cu}, \mathrm{Fe}, \mathrm{Pb}$ and $\mathrm{Zn}$ in the muscle tissues of both sexes (Table 2) indicated that zinc was the highest accumulated metal $(46.6,45.4 \mathrm{ppm})$, followed by copper $(24.4,36.6 \mathrm{ppm})$, iron $(21.8,36.2 \mathrm{ppm})$ and lead $(3.9,4.6 \mathrm{ppm})$, while cadmium was the lowest $(0.9 \mathrm{ppm})$ in males and females respectively.

Table 2: Mean concentrations of some heavy metals recorded in the muscle tissues of $C$. natator (values expressed as $\mathrm{mg} / \mathrm{kg}$ )

\begin{tabular}{|c|c|c|c|c|c|}
\hline Sex & Cd & Cu & Fe & Pb & Zn \\
\hline Male & $0.92 \pm 0.1$ & $24.39 \pm 5.01$ & $21.75 \pm 2.5$ & $3.87 \pm 1.1$ & $46.64 \pm 2.1$ \\
female & $0.90 \pm 0.1$ & $35.85 \pm 9.8$ & $35.75 \pm 4.9$ & $4.42 \pm 0.7$ & $46.11 \pm 2.0$ \\
\hline
\end{tabular}

Legend: $\mathrm{SD}=$ Standard deviation.

Figures 3 and 4 demonstrate the mean concentrations $(\mathrm{mg} / \mathrm{kg})$ for the determined heavy metals in relation to the crab's body size. It is evident from the figures that female crabs with carapace widths between 90-100,120-130mm accumulated more $\mathrm{Cu}$ and $\mathrm{Fe}$ than males of the same size ranges. However, the largest females $(120-130 \mathrm{mmCW})$ accumulated higher percentages of lead than did males within the same size. In males, concentration of $\mathrm{Cd}$ remained unchanged $(0.9 \mathrm{ppm})$ in the different size classes whereas $\mathrm{Cu}$ levels showed a marked increase towards larger sizes. $\mathrm{Fe}$ and $\mathrm{Pb}$ declined in small size ranges but increased $(22.8,4.1 \mathrm{ppm})$ in individuals between 140-150mm CW respectively. In contrast, values of $\mathrm{Zn}$ fluctuated in the different size categories. In females, $\mathrm{Cd}$ increased slightly in small individuals and remained fairly constant $(0.9 \mathrm{ppm})$ in the two large size classes (110-120, 120-130). Levels of $\mathrm{Cu}$ and $\mathrm{Fe}$ varied with sizes, whereas $\mathrm{Pb}$ and $\mathrm{Zn}$ increased with increased crab size.

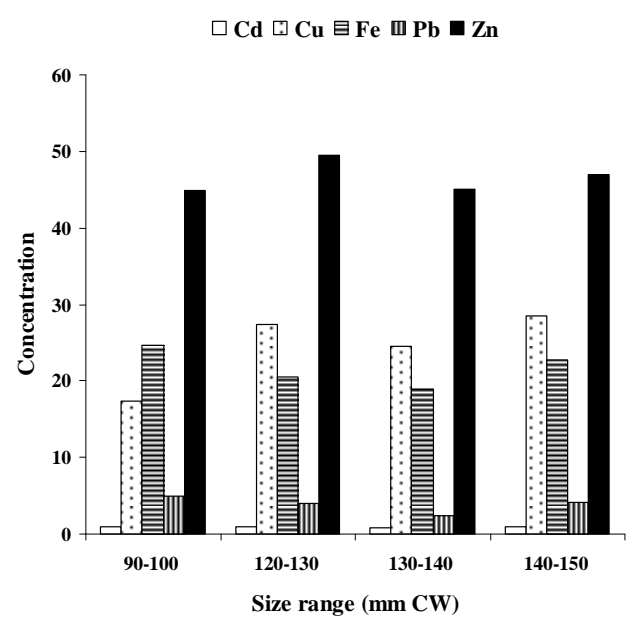

Fig. (3). Mean concentrations of the different heavy metals in the muscle tissues of male C. natator in relation to body size. 


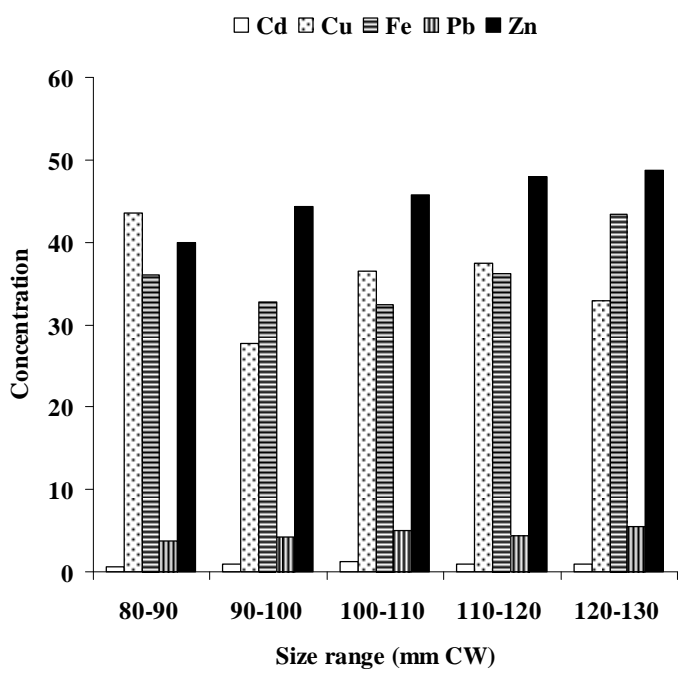

Fig. (4). Mean concentrations of the different heavy metals in the muscle tissues of female $C$. natator in relation to body size.

Table 3 illustrates the organoleptic qualities for C. natator and Portunus pelagicus after cooking. The results of the test ranked $P$. pelagicus as higher in organoleptic qualities. The analysis of variance (one-way ANOVA) revealed significant differences between the color, taste and acceptability $(P=0.023$, $0.036,0.030$ ) respectively (Table 4$)$. However, no significant difference was observed for the total acceptability of the two species $(P \geq 0.05)$.

Table 3: Organoleptic qualities of C. natator and P. pelagicus

\begin{tabular}{|l|c|c|}
\hline $\begin{array}{c}\text { Crab species } \\
\text { Organoleptic quality }\end{array}$ & Charybdis natator & Portunus pelagicus \\
\hline Aroma (10) & $8.9 \pm 1.3$ & $7.7 \pm 1.3$ \\
Color (10) & $9.1 \pm 1.2$ & $7.6 \pm 1.2$ \\
Texture (10) & $9.1 \pm 0.8$ & $7.5 \pm 1.4$ \\
Taste (10) & $9.3 \pm 0.8$ & $7.8 \pm 1.3$ \\
Acceptability (10) & $9.2 \pm 1.0$ & $7.7 \pm 1.1$ \\
Total acceptability (50) & $45.6 \pm 4.2$ & $38.4 \pm 5.3$ \\
\hline
\end{tabular}

\section{DISCUSSION}

Studies on the biochemical composition of economic species as well as their trace metals uptake are carried out to assess the nutritive quality and safety of these species for human consumption. The present study aimed at assessing the suitability of the portunid crab C. natator from the Gulf of Suez as food. Results indicated that the muscle tissues of this species had a relatively high percentage of protein, lipids and carbohydrates in both sexes $(82,8,6 \%)$ 
respectively. Protein and carbohydrate contents recorded in this study were higher than those reported for other species of Charybdis, though fairly similar for lipids (Siddiqui et al., 1987). Balasubramanian and Suseelan (2001) reported that the muscle tissues of Charybdis smithii from the seas around India have a protein percentage varying between 60 and $71 \%$ of dry weight. Lipids ranged between 6.2 and $8.2 \%$, while carbohydrates contributed with $2.4-3.4 \%$. Furthermore, values recorded in this study were higher than those reported for other edible crab species including Podophthalmus vigil (Radhakrishnan \& Natarajan, 1979) and the commercial species Portunus pelagicus in particular (Sallam et al., 2006). Akbar et al. (1988) reported a range of 54-75\% for protein and 3.2-6.2\% for lipids for P. pelagicus in Pakistan, while Pillay and Nair (1978) reported $40.1-60.7 \%$ for protein and $1.3-6.15 \%$ for lipids for the same species in India. These results reflect the high nutritive quality of $C$. natator and indicate that both males are females and equally rich in protein.

Metal bioaccumulation by marine organisms has been the subject of considerable interest in recent years because of serious concern that high levels of metals may have detrimental effects on the marine organisms that can affect their suitability as food for humans (El-Moselhy \& Gabal, 2004). In Charybdis natator, metal accumulation followed the order: $\mathrm{Zn}>\mathrm{Cu}>\mathrm{Fe}>\mathrm{Pb}>\mathrm{Cd}$. The levels of $\mathrm{Cd}, \mathrm{Zn}, \mathrm{Fe}, \mathrm{Cu}$ detected during this study were extremely low in comparison to those reported for other edible crab species (Ghazaly, 1988; Sallam et al., 2006; Reddy et al., 2007). This could be attributed to the nature of the environment surrounding the crab or to its feeding habits which results in the accumulation of metals. However, the relatively high levels of lead recorded herein could be related to the activity of oil exploration and production close to Gemsha Islands in the Gulf of Suez. Emara et al. (1999) recorded a concentration of $883 \mathrm{ppm}$ for petroleum hydrocarbons in the sediment of Gemsha area. High lead concentrations have been also reported in areas polluted with petroleum hydrocarbon such as the Lithuanian offshore of the Baltic Sea (Jokšas et al., 2005). Despite being within the permissible limits (WHO, 1982), concentrations of lead in $C$. natator require continuous monitoring. Wittman (1981) stated that lead and cadmium are non essential metals which arise mainly from anthropogenic sources, indicating the levels of pollution to which the organism is subjected.

In the present study, levels of metals varied between sexes of $C$. natator where females accumulated higher concentrations than males. Intra-specific differences in metals uptake have been reported for P. pelgicus in the Gulf of Suez (El-Moselhy, 2006) and for other marine organisms (Sadiq \& Alam 1992). Latouche \& Mix (1982) mentioned that metal accumulation within somatic tissues did not differ between sexes, and if variation exists, it is restricted only prior to spawning season as a result of variations in the amount of metals present in the gametes of the two sexes and disappear afterwards. On the other hand, variations in the levels of some metals were noticeable in the different sizes of 
both sexes. Size- based variations in metal accumulation has been reported in the edible swimming crab Carcinus maenas (Bjerregaard \& Depledge, 2002).

No significant differences were recognized in the aroma and texture of meats of C. natator and P. pelagicus. The assessors were not able to differentiate between them. Conversely, meat of the latter species was found to have a whiter appearance and more acceptable taste than the first. Variations in taste could be related to freshness of the samples. P. pelagicus was freshly caught whereas $C$. natator remained iced aboard trawlers for quite sometime throughout the fishing trip in the Gulf of Suez before introduction to the market. Whiter appearance of flesh was related to high fat content in cultured fishes (Gabr \& Gab-Alla, 2007). Moreover, lipid content in C. natator was lower (7.5\%) than P. pelagicus (14\%) (Sallam et al., 2006). Nevertheless, the absence of significant differences in the total acceptability of meats of both crabs indicates that this species is edible and therefore suitable for human consumption.

The high nutritive quality of this species, as well as its safe, less contaminated, palatable flesh encourages us to raise awareness on its suitability as appropriate seafood. The fact that cooking renders the shell more breakable should be brought to the attention of consumers. This would hopefully increase popularity of this species and boost its sales. Care should be given to the manner to achieve maximum benefits of this protein rich meat. One possibility is to introduce it to consumers in a processed way at affordable prices. Since $P$. pelagicus is extensively fished in the Egyptian waters, C. natator fishing may come as a welcome supplement. This will obviously popularize its meat as a valuable source of protein and will eventually bridge the protein gap, which is badly needed at present.

\section{REFERENCES}

Abdel-Razek, F.A. (1988). Some biological studies on the Egyptian crab Portunus pelagicus (Linnaeus, 1766). Acta Adriatica, 29 (1/2): 133143.

Akbar, Z.; Qasim, R. and Siddiqui, J.A. (1988). Seasonal variations in biochemical composition of edible crab (Portunus pelagicus Linneaus) J. Isl. Acad. Sci., 1(2): 127-133.

Al-Kholy, A.A. and El-Hawary, M.M. (1970). The biology of Lupa pelagica (Linnaeus). Bull. Biol. Ins. Ocean. Fish., 1:397-423.

APHA (1995). The American Public Heath Association, Standard methods for the examination of water and waste water. 19th Edition, Washington DC. 
Balasubramanian, C.P. and Suseelan, C. (2001). Biochemical composition of the deep- water crab Charybdis smithii, Ind. J. Fish., 48(3): 333-335.

Barnard, K.H. (1950). Descriptive catalogue of South African Crustacea (crabs and shrimps). Ann. S. Afr. Mus, 38: 1-824.

Barns, H. and Blackstock, J. (1973). Estimation of lipids in marine animals and tissues, detailed investigation of the sulphophosphovanillin method for total lipids. J. Exp. Mar. Biol. \& Ecol., 12: 103-118.

Batoy, C.B.; Sarmago, J.F. and Pilapil, B.C. (1987). Breeding season, sexual maturity and fecundity of the blue crab Portunus pelagicus (L.) in selected coastal waters in Leyte and Vicinity, Philippines. An. Trop. Res., 2: 157-177.

Batoy, C.B.; Pilapil, B.C. and Sarmago, J.F. (1988). Size composition, distribution, length-weight relationship and natural food of the blue crab Portunus pelagicus (L.) in selected coastal waters in Leyte and Vicinity, Philippines. An. Trop. Res., 10(3/4): 127-142.

Bawab, F.M. and El-Sherif, S.S. (1988). Stages of the reproductive cycle of the female crab Portunus pelagicus (Linnaeus, 1758) based on the anatomical changes of the spermatheca. Crustaceana, 54:139-148.

(1989). Contributions to the study of the origin, nature and formation of the plug in the spermatheca of the female crab Portunus pelagicus (Linnaeus, 1766) (Decapoda, Brachyura). Crustaceana, 57(1):9-24.

Bjerregaard, P. and Depledge, M. (2002). Trace metal concentrations and contents in the tissues of the shore crab Carcinus maenas: effects of size and tissue hydration. Mar. Biol., 141(4): 741-752.

Boyden, C.R. (1977). Effect of size upon metal content of shellfish. J. Marine Biol. Ass. U.K, 57:675-714.

Dubois, M.; Giles, K.A.; Hamilton, J.K.; Rees, P.A. and Smith, F. (1956). Colorimetric method for determination of sugar and related substances. Ann. Chem. 28: 350 pp.

El-Moselhy K.H. (2006). Bioaccumulation of total mercury in marine organisms from Lake Timsah and Bitter Lakes (Suez Canal, Egypt). Egypt. J. Aqua. Res., 32(1):124-134 
El-Moselhy K.H. and Gabal, M.N. (2004). Trace metals in water, sediments and marine organisms from the northern part of Gulf of Suez, Red Sea. J. Mar. Sys., 46: 39-46.

Emara, A.M. (1999). Surveillance and biological studies on the intertidal mollusks along the western coast of the Gulf of Suez, Egypt. PhD Thesis., Tanta University.

Gabr, H.R and Gab-Alla, A.A.F. (2007). Comparison of biochemical composition and organoleptic properties between wild and cultured fish. J. Fish. Aqua. Sci., 2(1): 77-81.

Ghazaly, K.S. (1988). The bioaccumulation of potential heavy metals in the tissues of the Egyptian Edible marine animals, Part 1. Crustaceans. Bull. Biol. Ins. Ocean. Fish A.R.E., 4 (2): 71-77.

Jokšas, K.; Galkus, A. and Satakènienè, R. (2005). Geogological state of the Lithuanian offshore of the Baltic Sea, the lower beaches of Nemunas and the Cutonian lagoon. Acta Zoologica Lilloana., 15(2):119-123.

Kangas, M.I. (2000). Synopsis of the biology and exploitation of the blue crab Portunus pelagicus Linnaeus in western Australia. Fish. Res. Rep., 121: 1-22.

Klein, B.P. and Bardy, P.L. (1984). Experimental foods. Department of food nutrition, University of Illinois, U.S.A.

Latouche, Y. D. and Mix, M. C. (1982). The effect of depuration, size and sex on trace metals levels in Bay mussels. Mar. Poll. Bull., 13: 27-29.

Lawry, O.H.; Rosebrough, A.L.; Farr, A.L. and Randell, R.G. (1951). Protein measurement with folin - phenol reagent. J. Biol. Chem., 193: 265275.

Menon, M.K. (1952). A note on the bionomics and fishery of the swimming crab Neptunus sanguinolentus (Herbst) on the Malabar coast. J. Zool. Soc. of Ind., 4: 177-184.

Pillay, K. K. and Nair, N. B. (1973). Observations on the biochemical changes in gonads and other organs of Uca annulipes, Portunus pelagicus and Metapenaeus affinis (Decapoda: Crustacea) during the reproductive cycle. Mar. Biol., 18: 167-198. 
Radhakrishnan, C.K. and Natarajan, R. (1979). Nutritive value of the crab Podophthalmus vigil (Fabricius). Fish Tech., 16: 37-38.

Reddy, M.S.; Mehta, B.; Dave, S.; Joshi, M.; Samra, V.K.S.; Basha, S.; Ramachandraiah, G. and Bhatt, P. (2007). Bioaccumulation of heavy metals in some commercial fishes and crabs of the Gulf of Cambay, India. Cur. Sci., 92(10-11): 1489-1491.

Sadiq, M. and Alam, I. A. (1992). Bioaccumulation of mercury by clams (Meretrix meretrix) collected from the Saudi Coast of the Arabian Gulf. Chem. Spec. \& Bio. 4 (1): $9-17$.

Sallam, W.S.; Temraz, T.A. and Gabr, H.R. (2006). Biochemical compositions and heavy metals accumulation in some commercial crustaceans from the Mediterranean coast off Port Said, Egypt. J. Egypt. G. Soc. Zool, (Inv. Zool. \& Parasitol.), 51D: 127-141.

Siddiquie, P.J.A.; Akbar, Z. and Qasim, R. (1987). Biochemical composition and caloric values of the three edible species of portunid crabs from Karachi (Pakistan). Pak. J. Sci. Ind. Res., 30 (2): 119-121.

Stephenson, W.; Hudson, J.J. and Campbell, B. (1958). The Australian Portunidae (Crustacea: Portunidae). II. The genus Charybdis. Aust. J. Mar. Freshw. Res., 8: 491-507.

Sumpton, W.D. (1990 a). Biology of the rock crab Charybdis natator (Herbst) (Brachyura: Portunidae). Bull. Mar. Sci., 46(2): 425-431.

Sumpton, W.D. (1990b). Morphometric growth and fisheries biology of the crab Charybdis natator (Herbst) in Moreton Bay, Australia (Decapoda, Brachyura). Crustaceana., 59(2): 113-120.

Wang, H.; Wu, H.; Wang, Z.; Wang, X and Wang, Sh. (2001). Fisheries biology of Portunus pelagicus (L) initiating investigation. Mar. Sci. HaiyangKexue, 25 (1): 36-39.

WHO, (1982). Toxicological evaluation of certain food additives, WHO Food Addit. Ser. No.17, World Health Org., Geneva, pp. 28-35.

Wittman, G. (1981). Toxic metals. In, Metal pollution in the aquatic environments, eds. Wittman, G. \& Fröstner. Springer Verlag, 486 pp.

Zaghloul, S.S. (2003). Studies on the reproductive biology and rearing of portunid crabs in Suez Bay. Ph.D. thesis, Suez, Suez Canal University. 